\title{
Thyroid nodules - Stepwise diagnosis and management
}

\author{
Stergios A. Polyzos, Marina Kita, Avraam Avramidis \\ Department of Endocrinology, "Hippokratio" General Hospital, Thessaloniki, Greece
}

\begin{abstract}
Thyroid nodules are common in clinical practice. They may be solitary within a "normal" thyroid gland or dominant within a multinodular goiter. The incidence of thyroid nodules has been on the rise in recent decades, mainly due to the wider use of neck imaging. Therefore, the incidental finding of a thyroid nodule in an asymptomatic patient is not rare. The differential diagnosis of a thyroid nodule is crucial, as malignancy necessitates surgery, while strict patient follow-up is necessary in the case of benignity. Fine-Needle Aspiration biopsy is considered to be the "gold standard" in the selection of patients for surgery. Ultrasonography (US) can be used to determine changes in the size of nodules during follow-up or to detect recurrent lesions in patients suspected for thyroid malignancy, although there are no specific US findings that suggest malignancy. Surgery is mandatory in cytologically malignant nodules or in cases suspicious for malignancy. The definite diagnosis and consequent therapy is based on the histological findings after surgery. In this review we present an approach to thyroid nodules in five distinct steps, from the clinical or incidental finding of a nodule to the suggested treatment baselines.
\end{abstract}

Key words: FNA, Goiter, Thyroid adenoma, Thyroid carcinoma, Thyroid malignancy, Thyroid nodule

\section{THE THYROID NODULE}

\section{Epidemiology}

A thyroid nodule is a discrete lesion within the thyroid gland that is palpably and/or sonographically distinct from the surrounding thyroid parenchyma. A solitary thyroid nodule exists within a thyroid gland of normal dimensions and morphology, whereas a

\footnotetext{
Address for correspondence:

Stergios Polyzos, Department of Endocrinology, Hippokratio General Hospital, 49 Konstantinoupoleos Str,

54642 Thessaloniki, Greece, Tel.: +30 2310455780 ,

Fax: +302310 848353, e-mail: stergios@endo.gr

Received 05-02-07, Revised 20-03-07, Accepted 25-03-07
}

dominant thyroid nodule exists within a diffuse or multinodular goiter. ${ }^{1}$

Thyroid nodules come to clinical attention when noted by the patient or as an incidental finding during routine physical examination or during a radiologic procedure, such as carotid ultrasonography (US) or neck computed tomography (CT). Several disorders may be the cause of a thyroid nodule. The majority of thyroid nodules are asymptomatic. Their clinical importance is primarily related to the need to exclude a thyroid malignancy. ${ }^{2-6}$

Thyroid nodules are very common, with an estimated prevalence of approximately $4 \%$ by palpation 
(5\% in women and $1 \%$ in men living in iodine-sufficient regions). ${ }^{6,7}$ A thyroid nodule larger than 1 $\mathrm{cm}$ in diameter is usually palpable. However, the detection of a nodule by palpation also depends on its location within the thyroid, on the structure of the patient's neck and on the experience of the examiner. ${ }^{89}$ In the Framingham Study, clinically apparent thyroid nodules were present in $6.4 \%$ of the women and $1.6 \%$ of the men who participated, with an estimated annual incidence, by palpation, of $0.001 .^{6}$ The lifetime risk of developing a thyroid nodule is reported to be $15 \% .{ }^{6}$ Nevertheless, only $5 \%$ of the clinically apparent thyroid nodules are malignant. Thyroid carcinoma annual incidence is 1-2 per 100,000 population, which accounts for $90 \%$ of the malignancies of the entire endocrine system, $1 \%$ of total human malignancies and $0.5 \%$ of total deaths from malignancies. ${ }^{10,11}$ Although thyroid malignant tumors are not usually aggressive, thyroid malignancies are responsible for more deaths than all other malignancies of the endocrine system. ${ }^{11}$

Due to the wide use of US, the prevalence of thyroid nodules has increased to within a range of $20 \%$ to $67 \%$ in randomly selected populations, with a higher frequency in women and the elderly. This means that a thyroid nodule found incidentally in an asymptomatic patient (thyroid incidentaloma) is not rare. ${ }^{12-15}$ Moreover, in patients with a clinically palpable nodule the US may identify additional nodules in $20-48 \%$ of subjects. ${ }^{15}$ Thus, the use of US alters the primary evaluation of thyroid nodularity based on palpation. ${ }^{8}$ In addition, the prevalence of thyroid nodules in patients with no history of thyroid disease was $37-57 \%$ in surveys based on autopsy. ${ }^{16,17}$

Thyroid nodules are more frequent in women, in iodine deficient regions, in older ages ${ }^{17,18}$ and in patients with a history of head or neck irradiation in childhood, which was extensively used in the past for the treatment of acne, tonsillitis, adenoiditis and thymus gland enlargement. ${ }^{19}$

Thyroid nodules constitute a diagnostic challenge mainly because of the need to exclude thyroid malignancy. It is also necessary to exclude nodulary hyperfunction (autonomous adenoma or toxic multinodular goiter).

Risk factors that increase the probability of ma- lignancy of a thyroid nodule are age under 30 or over 60 years, ${ }^{20-22}$ male sex ( $8 \%$ versus $4 \%$ in female), ${ }^{20,23,24}$ history of head and neck irradiation in childhood ${ }^{21,25}$ and family history of medullary thyroid carcinoma (MTC) or multiple endocrine neoplasia (MEN) type $2 .{ }^{26}$

Thyroid carcinoma clinically presents as a solitary or dominant nodule in the majority of cases. Nonetheless, most thyroid nodules are not malignant. In a study of patients who underwent surgery without previous fine-needle aspiration biopsy (FNA), 6.5\% of the excised nodules were carcinomas. ${ }^{4}$ In another study, thyroid carcinomas were found in 5\% of 2327 patients presenting with nodule(s). ${ }^{27}$ Differentiated thyroid carcinomas [papillary (PTC) and follicular (FTC)] constitute $90 \%$ of all thyroid malignancies. Younger patients (under 40) with PTC have better prognosis with a 25 -year mortality less than $2 \%$ after surgical excision. ${ }^{28}$ However, approximately $15 \%$ of differentiated thyroid carcinomas may be more aggressive and can metastasize regionally or distantly. Invasion of the thyroid capsule is related to increased long-term mortality. ${ }^{29}$ Anaplastic thyroid carcinoma (ATC), MTC and thyroid lymphoma have higher mortality, but they are less frequent than the differentiated thyroid carcinomas. ${ }^{29}$

With regard to the incidence of thyroid nodules in Graves' disease, a prospective study of 245 patients indicated that $35 \%$ of them had thyroid nodules and at least $3.3 \%$ had thyroid malignancy, most of which were micropapillary carcinomas (one of eight carcinomas was palpable). In other words, $9.2 \%$ of thyroid nodules were malignant compared to approximately $5 \%{ }^{27}$ of thyroid nodules without coexistent Graves' disease. The authors did not recommend routine US in patients with Graves' disease. They noted that the risk of malignancy was higher in patients over 45, regardless of the duration or severity of hyperthyroidism or goiter size. Stimulating TSH-receptor antibodies does not seem to induce nodule/carcinoma formation or a change in the biologic behavior of thyroid malignancies in patients with Graves' disease..$^{30}$

As regards cost-effectiveness, it has been reported that the patients' visit to an endocrinologist before undergoing imaging evaluation contributes to decreasing the diagnostic cost and increasing diagnostic 
efficacy. ${ }^{31}$

With regard to goitrous multinodularity, some studies suggested that the frequency of carcinoma in multinodular goiters is about half of that found in solitary nodules..$^{32,33}$ Other studies, however, indicated that goitrous multinodularity should no longer be considered as an indicator of benign disease and that the nodules within a multinodular goiter should be valued as the solitary nodules in an otherwise normal gland. ${ }^{34-37}$ According to the European Thyroid Cancer Taskforce, the risk of malignancy is similar among hypofunctioning solitary nodules and multinodular goiter. $^{38}$

\section{Differential Diagnosis}

The differential diagnosis of the thyroid nodule is detailed in Table $1 .^{1,3,39-53}$

\section{STEPWISE MANAGEMENT}

\section{Step 1: Physical examination}

Although thyroid nodules have an estimated prevalence of about $4 \%$ by palpation, ${ }^{6}$ the accuracy of clinical diagnosis of thyroid malignancy is low. Nonetheless, some patients with high clinical suspicion of malignancy need surgical treatment whatever the FNA result may be; those with lower degrees of clinical suspicion and malignant or uncertain FNA result should also undergo surgery. ${ }^{54}$ Clinical indications of malignancy may be: the size of the nodule (more suspicious if greater than $4 \mathrm{~cm}$ to palpation), ${ }^{23}$ gradual increase of the nodule's size (especially when the subject is under suppressive treatment with thyroxin), hardness and firmness of a nodule, cervical lymphadenopathy, distant metastases, hoarseness (vocal cord paralysis), dysphagia, obstruction, local pain, Horner's syndrome. ${ }^{2,38}$ Sudden increase in the nodule's size is more indicative of haemorrhage inside the nodule, therefore surgical excision is not recommended. ${ }^{55,56}$

\section{Step 2: Laboratory investigation}

\section{Thyroid Stimulating Hormone (TSH) - Antithyroid antibodies}

The majority of patients with begnin or malignant thyroid nodule(s) are euthyroid. Despite this, serum $\mathrm{TSH}$ measurement is recommended in all patients presenting with a nodule. $1,38,57,58$

In the case of low serum $\mathrm{TSH}$, a radionuclide thyroid scintigraphy (SC) $\left({ }^{99} \mathrm{Tc}\right.$ or $\left.{ }^{123} \mathrm{I}\right)$ should be obtained to document whether the nodule is functioning (hot) or not. Functioning nodules rarely harbor malignancy. Hence, in the event of a functioning nodule, some authors suggest that no additional cytological evaluation is necessary. If overt or subclinical hyperthyroidism is present, additional evaluation of the hyperthyroidism is required. ${ }^{1}$

In cases of normal or high serum TSH, diagnostic thyroid US should be performed. ${ }^{1}$ Even if the TSH is high, FNA is recommended as the rate of malignancy in nodules within thyroid glands with Hashimoto's thyroiditis (high TSH) is similar to nodules within thyroid glands without Hashimoto's thyroiditis (normal TSH). If TSH is high, antithyroid antibodies (anti-TPO, anti-TG) should also be obtained to confirm the diagnosis of Hashimoto's thyroiditis. ${ }^{59,60}$ Apart from thyroiditis, the contribution of antithyroid antibodies to the differential diagnosis of thyroid nodules is poor. ${ }^{38}$

It has recently been reported that the risk of malignancy in a thyroid nodule increases proportionally to serum TSH concentrations at presentation, even within the normal range, and thus TSH was proposed as a novel independent predictor of the presence of thyroid malignancy. ${ }^{61}$

\section{Calcitonin}

The routine calcitonin measurement as a means to improve the preoperative diagnosis of MTC in nodular thyroid diseases remains controversial. ${ }^{58,62}$ Some authors reported that calcitonin evaluation detects MTC in cases where other procedures such as FNA cytology failed, thus allowing early radical surgery. They therefore suggest that calcitonin measurement should become a routine part of the diagnostic evaluation of nodular thyroid diseases. ${ }^{63-67}$ Others report that there is no absolute threshold value for basal calcitonin to discriminate thyroid MTC nodules from nodules of other etiology. Therefore, calcitonin measurement in every patient with nodular thyroid disease usually gives false-positive results and may not be cost-effective. ${ }^{6}{ }^{\text {The calcitonin measurement }}$ is proposed by $5 \%$ of the members of the American 
Table 1. Differential diagnosis of a "thyroid" nodule

\begin{tabular}{|c|c|c|}
\hline \multirow[t]{2}{*}{$\overline{\mathbf{A}}$} & Thyroidal neoplastic lesions & \multirow{2}{*}{$\begin{array}{l}\text { B } \text { Thyroidal non-neoplastic lesions } \\
1 \text { Cysts }\end{array}$} \\
\hline & I Benign & \\
\hline & 1 Dominant portion of multinodular goiter & - Thyroid \\
\hline & 2 Adenoma & - Thyroglossal \\
\hline & - Colloid & 2 Agenesis of a thyroid lobe \\
\hline & - Follicular & 3 Focal thyroiditis \\
\hline & - Fetal & - Hashimoto \\
\hline & - Embryonal & - De Quervain \\
\hline & - Hürthle cell & - Acute \\
\hline & - Teratoma & 4 Postsurgical remnant hyperplasia \\
\hline & - Lipoma & 5 Postradioiodine remnant hyperplasia \\
\hline & - Haemangioma & 6 Granulomatosis \\
\hline & II Malignant & - Sarcoidosis \\
\hline & 1 Papillary carcinoma & - Tuberculosis \\
\hline & 2 Follicular carcinoma & - Histiocytosis X \\
\hline & 3 Hürthle cell carcinoma & C Nonthyroidal lesions \\
\hline & 4 Medullary carcinoma & 1 Parathyroid cyst or adenoma \\
\hline & 5 Anaplastic carcinoma & 2 Inflammatory or neoplastic node \\
\hline & 6 Thyroid lymphoma & 3 Aneurysm \\
\hline & 7 Fibrosarcoma & 4 Cele of bronchus \\
\hline & 8 Haemangioendothelioma & 5 Laryngocele \\
\hline & 9 Histiocytoma & \\
\hline & 10 Teratoma & \\
\hline & 11 Metastatic carcinoma & \\
\hline
\end{tabular}

Thyroid Association during the assessment of a solitary thyroid nodule compared to $43 \%$ of the members of the European Thyroid Association. ${ }^{69}$

\section{Thyroglobulin}

Routine measurement of serum thyroglobulin for initial evaluation of thyroid nodules is not recommended. Serum thyroglobulin may be increased in many thyroid diseases and is considered an insensitive and non-specific test for thyroid malignancies. ${ }^{1,70}$

\section{Step 3: Thyroid imaging}

\section{Ultrasonography (US)}

US was first used to diagnose thyroid nodules in 1967 by Fujimoto. ${ }^{71}$ Current methods of US permit real-time identification of structures as small as 2 $\mathrm{mm}$ in diameter, thereby allowing the visualization of very small nodules. Doppler techniques can be added to differentiate cystic and vascular structures. ${ }^{72}$ It is more accurate than palpation in identifying solitary or dominant nodules within a multinodular goiter and it approaches the frequency of thyroid nodules found in autopsy studies. ${ }^{6,13,14,17}$ Among the advantages of US are the following: low cost, rapid investigation, acquisition of dynamic pictures, possibility of performing guided biopsies, easy accessibility and non-ionizing nature of the imaging. The high echogenicity of thyroid tissue and the superficial site of the thyroid gland allow the use of high-frequency transducers to yield high resolution. ${ }^{73,74}$

US is considered to be more sensitive than the physical examination and SC in detecting thyroid nodules. ${ }^{9}$ US provides more structural, albeit less functional items of information than the thyroid SC. ${ }^{9,75,76}$ Furthermore, approximately $20-25 \%$ of the lesions thought to be solitary on SC were found to be multinodular on US. ${ }^{76}$ Similarly, almost $50 \%$ of the patients referred for a solitary nodule on physical examination were found to have multiple nodules on US. ${ }^{37}$ Compared to cervical computed tomography 
(CT), the ability of US to detect small nodules makes it the procedure of choice in evaluating suspected intrinsic thyroid abnormalities. On the other hand, CT appears to be advantageous in detecting substernal thyroid extension and confirming thyroiditis. Both US and CT lack histological specificity, thus cannot differentiate malignant from benign nodules. ${ }^{77}$

US allows determination of thyroid lobes size and nodule size, echo structure (diffuse, uninodular or multinodular), echogenicity (iso-, hyper- or hypoechoic structures) and evaluation of adjoining neck structures. A solid thyroid nodule may be isoechoic, hypoechoic or hyperechoic compared to the surrounding thyroid tissue. ${ }^{74,75}$ Haemorrhage within a nodule changes the US pattern. A clot within the nodule may be hyperechoic and part of the nodule may be hypoechoic after liquefaction of the clot so that it looks cystic; this is a sonographically mixed nodule. A mixed nodule may also result from cystic degeneration of a solid nodule. On the other hand, a true simple thyroid cyst is an echo-free lesion with echoic amplification behind it. It is spherical and lined by a thin layer of cells without internal structure. Over time, colloidal or cell aggregations may be created inside the thyroid cysts, which provide a more echoic pattern. Thus, it is rather difficult to differentiate a thyroid cyst with such internal aggregations from a thyroid nodule with cystic degeneration and both are sometimes considered as "cystic" nodules. For this reason, the probability of malignancy of a "cystic" nodule differs widely. Some studies have shown very low incidence of malignancy in cystic nodules $(0.5-3 \%),{ }^{41,78-80}$ whereas others have shown a similar incidence to that of sonographically solid nodules. In cystic nodules, most of the cysts in patients with carcinoma measure 2 to $4 \mathrm{~cm}$ in diameter. The carcinoma was found within the cystic cavity, which appears to originate from the necrosis of the tumor. ${ }^{81-83}$ Hence, it is recommended that all "cystic" thyroid nodules be assessed to exclude underlying malignancy. This cannot be predicted from the cyst's clinical characteristics or the patient's demographic data. ${ }^{81,84,85}$ Cystic nodules that clinically disappear after evacuation by FNA are usually benign. ${ }^{86}$ Cystic nodules larger than $2 \mathrm{~cm}$ in diameter, nodules with haemorrhagic content and nodules that reappear after evacuating FNA are more suspicious for malignancy. ${ }^{80,87}$ In these reappearing nodules, FNA should be repeated or, alternatively, the patient should undergo thyroidectomy..$^{81,82,84}$

Several studies have been designed in order to evaluate whether US can be used in the differentiation of benign and malignant thyroid nodules. US findings diagnostic of malignancy do not exist. Nevertheless, helpful US parameters in clinical decision are: $: 38,73,74,88-90$

1) Echogenicity: Although most malignancies tend to be hypoechoic, benign nodules may be hypoechoic too. Yet, the intensity of echoes is considered very useful in making the US diagnosis: the rate of malignancy is considered extremely low in both hyperechoic and echo-free lesions. In a 401-patient study, $62 \%$ of malignancies were hypoechoic nodules. ${ }^{76}$ In another 132-patient study in which ultrasound-guided FNA (US-FNA) was performed, none of the 14 malignancies was hyperechoic. ${ }^{91}$

2) Peripheral "halo": It is only indicative of an intermediate, more hypoechoic region between the nodule and the surrounding thyroid tissue. It may be a capsule, compressed or atrophic thyroid tissue, local inflammation or edema. When it is splitting, irregular or absent, the nodule is considered by some authors as suspicious for malignancy. ${ }^{76}$

3) Calcifications: They can be amorphous, globular, nodular or linear and may occur in both adenomas and carcinomas without having specific diagnostic value, except for psammomatous calcifications, which are considered by some authors as a pathognomonic finding of PTC and by a small percentage of MTC ${ }^{92}$ Although their relation to malignancy seems to be controversial, ${ }^{93}$ the presence of intrinsic microcalcification seems the most statistically reliable criterion on which increased suspicion for malignancy in thyroid nodules is based. ${ }^{92,94,95}$

4) Cervical lymph node metastatic lesions: Lymph nodes with metastasis from thyroid malignancy tend to become rounded and bulging and lose their hilar echoes as their structure becomes disrupted. ${ }^{73}$

5) Vascular flow and velocity: Colour Doppler can display the vascular flow and velocity. The use of Doppler flow analysis may improve the cancer predictive value of a thyroid lesion. Intranodular blood flow can be detected in a greater percentage of malignant 
nodules, although no study has been able to show a specific flow pattern for malignancy. ${ }^{74,88,89,96,97}$

Thyroid US is used by $34 \%$ and $59 \%$ of the members of the American Thyroid Association in the assessment of a solitary thyroid nodule and nontoxic multinodular goiter, respectively, compared to $80 \%$ and $84 \%$ of the members of the European Thyroid Association. ${ }^{69,98}$ The wider use of US has resulted in perceptions of an "epidemic" of thyroid incidentalomas, which are incidentally found thyroid nodules in asymptomatic patients. These nodules may be discovered during carotid artery imaging, US evaluation for hyperparathyroidism or during US for other palpable thyroid abnormalities..$^{15}$ In a series of 259 patients, malignancy was identified in $5.8 \%$ of US-FNA for thyroid incidentalomas greater than $1 \mathrm{~cm}$, a prevalence similar to the one detected in a group with palpable thyroid nodules, and thus US-FNA is recommended in non-palpable thyroid nodules greater than $1 \mathrm{~cm}^{93}$

\section{Scintigraphy (SC)}

SC utilizes one of the radioisotopes of iodine (usually ${ }^{123} \mathrm{I}$ ) or technetium-99 pertechnetate $\left({ }^{99} \mathrm{Tc}\right.$ ). Normal thyroid follicular cells absorb both isotopes, but only radioiodine is organified and stored (as thyroglobulin) in the lumen of thyroid follicles. ${ }^{99}$ Nonetheless, ${ }^{99} \mathrm{Tc}$ is considered to be the radiopharmaceutical of choice for thyroid SC, due to its lower cost, good availability, lower radiation dose to the thyroid, good quality images within 20-30 minutes ( ${ }^{123}$ I needs 24 hours) and no need of T3 administration as a TSH suppressive hormone. ${ }^{100,101}$

SC provides functional rather than morphological information, contrary to US. Its use is recommended in patients with suppressed TSH to document whether a nodule is functioning or not. ${ }^{1,76,102}$ According to its uptake, a nodule is considered functioning or "hot" (i.e. has tracer uptake greater than the surrounding normal thyroid), isofunctioning or "warm" (i.e. has tracer uptake equal to the surrounding thyroid), non-functioning or "cold" (i.e. has uptake less than the surrounding thyroid tissue). ${ }^{1}$

Functioning nodules account for 5-10\% of palpable nodules, but thyroid malignancy is only a minority among them ${ }^{103-106}$ and, when it occurs, it usually be- haves less aggressively. ${ }^{107}$

On the other hand, most benign and malignant nodules have less uptake than the surrounding thyroid tissue ("cold" nodules). Three to eight per cent of thyroid nodules absorb ${ }^{99} \mathrm{Tc}$, but not ${ }^{123} \mathrm{I}$. They may appear hot or warm on ${ }^{99} \mathrm{Tc} \mathrm{SC}$ and cold on late (24 hours) ${ }^{123}$ I or ${ }^{131}$ I SC. ${ }^{99,100,108,109}$ This is known as the "trapping-only phenomenon". Although such nodules carry a risk of malignancy, they are usually benign. ${ }^{108-114}$ Therefore, it is recommended by some authors that patients with hot or warm nodules on ${ }^{99} \mathrm{Tc}$ SC undergo ${ }^{123} \mathrm{I} \mathrm{SC},{ }^{110,115}$ especially if serum TSH is not suppressed. ${ }^{109}$

SC has several limitations. Firstly, it has limited value in selecting patients for surgery because of its low specificity. In a study, only one-half of excised thyroid malignancies appeared cold on SC. ${ }^{103}$ Secondly, due to the fact that it is a two-dimensional technique, there is superimposition of abnormal nodular tissue and normal thyroid tissue. ${ }^{9}$ On account of such superimposition, small non-functioning nodules may appear warm rather than cold. ${ }^{103}$ Finally, if the production of thyroid hormone by a functioning nodule is insufficient to suppress TSH secretion, the functioning nodule may appear warm rather than hot. ${ }^{100,101}$

The role of SC in the routine evaluation of all patients with thyroid nodules is questionable according to some cost-effectiveness studies. ${ }^{5,116}$ Nonetheless, $23 \%$ of the members of the American Thyroid Association and $66 \%$ of the members of the European Thyroid Association routinely use SC to evaluate patients with solitary thyroid nodules. ${ }^{69}$

\section{Positron Emission Tomography (PET)}

Most PET imaging studies in head and neck malignancies are performed using the radiotracer 18fluorodeoxyglucose (18-FDG) ${ }^{117}$ Its use is increasing, but there is much controversy about its cost-effectiveness. ${ }^{118}$ It is usually employed in patients with metastatic disease. It offers valuable information in localizing a primary tumor in patients with neck nodal metastases from an unknown primary malignancy and in the detection of recurrent disease. After thyroidectomy, FDG-PET has proven useful in patients with clinical or serological evidence of recurrent or metastatic thyroid carcinomas but negative whole 
body radioiodine SC. PET reveals metastatic disease in up to $90 \%$ of these patients, thereby providing a rational basis for further studies and therapy. ${ }^{117}$

Occasionally, incidental intense FDG uptake is observed in the thyroid gland on whole body PET studies performed for other indications (PET incidentalomas). The prevalence of PET thyroid incidentalomas is $1.2-2.2 \% .{ }^{118,119}$ Although diffuse FDG uptake usually indicates thyroiditis, focal high uptake carries a risk of thyroid malignancy in about $15-30 \%$ of the cases. Therefore, thyroid PET incidentalomas should be further evaluated by FNA or undergo surgery. ${ }^{118,119}$

\section{Step 4: Cytology}

\section{Fine-Needle Aspiration biopsy (FNA)}

Any solitary or dominant thyroid nodule larger than $1 \mathrm{~cm}$ should be submitted to cytology, unless proven to be hyperfunctioning (low-suppressed TSH). Micronodules (smaller than $1 \mathrm{~cm}$ ) carry a very low risk of morbidity even if malignant and should be submitted to cytology only in the event of suspicious finding at US (solid hypoechoic with microcalcifications) or personal history. ${ }^{38}$

Several methods have been used to obtain groups of cells or tissue from thyroid nodules. The most prevalent method is FNA, which is considered to be the most accurate and cost-effective in the preoperative investigation of thyroid nodules. ${ }^{120}$ FNA is an invasive method, whose simplicity and safety justify its use for "selective" surgery and is considered the "gold standard" in the management of thyroid nodules. ${ }^{1,38}$

FNA is usually performed without local anesthesia and the patient does not require any previous preparation. The patient's neck should be extended. Aseptic conditions are necessary to prevent bacteria from seeding into the thyroid. ${ }^{45,121}$ The nodule is initially fixed between the index and middle finger of the aspirator. A 23- to 27-gauge needle can be employed, but a 25 -gauge needle is usually used. The needle is attached to a 10-ml syringe, which may be lodged in a holder for facilitating the application of continuous or discontinuous suction by repetitively moving through the nodule. The aspirated material is smeared directly on glass slides, fixed, stained and interpreted by a cytopathologist. ${ }^{122,123}$ The procedure should be repeated 4-6 times obtaining material from different sites of the nodule. By this means, the probability of a diagnostic result and a more representative specimen is increased. A final report can generally be rendered within 24 hours. ${ }^{123}$

Expertise at every level of the procedure is critical for obtaining good results. A skilful aspirator is a prerequisite as well as an experienced cytopathologist. ${ }^{122}$ In medical centers with long-standing experience, diagnostic (adequate) biopsies obtained from solid nodules range from 90 to $97 \% .^{5,87,124-131}$ It is more difficult to achieve a diagnostic biopsy from a cystic or mixed nodule. ${ }^{81,131}$

It has been reported that, although FNA is guided by palpation (conventional or non-US- or palpationguided FNA) in $87 \%$ of cases in North America and Europe, ${ }^{69}$ the US-FNA is becoming increasingly popular. During this procedure, US guidance is used instead of palpation, which seems to enhance the value of FNA diagnostic accuracy. ${ }^{132-134}$ US helps direct the needle tip to the desired site, avoiding vessels in close vicinity to the nodule or areas of central necrosis, which often yield nondiagnostic specimens. ${ }^{135}$ Nonetheless, it is not suggested that US-FNA be routinely used, because most clinically detected and palpable thyroid nodules may be aspirated directly without US guidance, thereby contributing to lower cost. ${ }^{76,136}$ Although there are no specific guidelines, it is suggested that US-FNA be performed in: : $34,93,132,135-137^{-1}$ 1) nonpalpable nodules larger than $1 \mathrm{~cm}$ (they have the same risk of malignancy as palpable of the same size), 2) nodules palpable but smaller than $1.5 \mathrm{~cm}, 3$ ) deeply found nodules (to avoid pleura's puncture), 4) nodules in close vicinity to blood vessels, 5) cystic or mixed nodules, especially if a previous conventional FNA was nondiagnostic, 6) nodules after a nondiagnostic conventional FNA, 7) coexistent nonpalpable lymphadenopathy.

\section{- FNA complications}

FNA is generally a very safe procedure. Clinically important complications after FNA have rarely been reported. Haematoma formation is rare, albeit the most commonly encountered complication. Massive intrathyroid haemorrhage producing acute upper 
airway obstruction occurs very rarely. The former resolves in days, whereas the latter requires surgical treatment. ${ }^{50,138,139}$ Doppler US can be used to identify and avoid puncturing blood vessels near the nodule(s). In this way, haematoma formation is avoided and the quality of the specimens is improved. ${ }^{96}$

Local metastasis of thyroid malignancies from needle track seeding during FNA is a rare, albeit possible, complication of thyroid FNA. Although the appropriate FNA technique can reduce the potential of needle track seeding, its occurrence is an unavoidable complication of FNA evaluation of thyroid malignancies. ${ }^{140-142}$ Extrusion of the tumor parenchyma through the capsular interruption in follicular thyroid adenomas $^{143}$ and vascular proliferation ${ }^{50,144}$ after FNA have also been described.

Ischemic necrosis associated with infarction, despite its rarity, may cause diagnostic problems. FNA yielding necrotic debris may result in false negative results in repeat aspiration and post-FNA infarction may obscure the nature of a neoplasm evaluated by FNA, making histological confirmation difficult. ${ }^{121,145,146}$

Pneumothorax, thyrotoxicosis, infection induced by needle-track seeding and inflammatory reactions after FNA have rarely been reported. ${ }^{45,121,123,145,147}$

\section{- Evaluation of FNA results}

The results of cytological examination of samples obtained by FNA or Fine-Needle Capillary (FNC) biopsy can traditionally be categorized in four classes, as below: ${ }^{1,5}$

1. Benign (70\%), includeing mainly macrofollicular or "colloid" adenomas, the dominant portion of multinodular goiters and Hashimoto's thyroiditis.

2. Suspicious or indeterminate (10\%), including follicular and Hürthle cell neoplasms (microfollicular or cellular adenomas).

3. Malignant (4\%), including primary and metastatic thyroid malignancies.

4. Nondiagnostic (inadequate) smears (16\%).

FNA is limited by nondiagnostic smears and indeterminate results. ${ }^{120}$ Ten to twenty per cent of all speci- mens remain nondiagnostic. ${ }^{5,120,132,134}$ Nondiagnostic biopsies are those that fail to meet specified criteria for adequacy. Although the criteria for considering a specimen diagnostic vary among institutions ${ }^{148,149}$ an accepted definition includes 6 or more groups of 10 to 20 well-preserved follicular epithelial cells per group on at least 2 slides. ${ }^{148}$ The repetition of FNA on initially nondiagnostic cases produced diagnostic results in more than half of the cases. ${ }^{2,148}$

Approximately $10 \%$ of all FNA biopsies are considered indeterminate or suspicious because of overlapping cytological features. ${ }^{58,150}$ In particular, FTC and Hürthle cell carcinoma (HCC) cannot be distinguished cytologically from follicular and Hürthle-cell adenomas, respectively, after FNA. ${ }^{120,151,152}$ These nodules are classified as carcinomas if capsular or vascular invasion are found histologically after surgery.

\section{Fine-Needle Capillary biopsy (FNC)}

$\mathrm{FNC}$ is an alternative to FNA technique. In $\mathrm{FNC} \mathrm{a}$ fine needle without the application of syringe suction for negative pressure is used. The cells are detached by the cutting edge of the needle and are conducted into the lumen by capillary force. The sample is expelled on a glass slide, which is smeared, fixed, stained and submitted for cytological interpretation exactly as in FNA. ${ }^{153,154}$

FNC offers a series of advantages. Trauma to cells and tissues is reduced without aspiration. Less blood in the samples results in higher quality cytological smears. The needle is handled by the wrist and fingertips (by contrast with FNA, in which the syringe holder is handled by the shoulder) allowing more precise puncture. Finally, FNC causes less pain than FNA. ${ }^{155}$

FNC is considered by some authors to provide qualitatively superior smears ${ }^{154,156}$ On the other hand, some authors found no statistical difference in the diagnostic capability of the two methods. ${ }^{153}$ Until further experience clarifies sampling superiority of FNA or FNC, performing combined FNA and FNC would improve the quality and quantity of the material obtained. ${ }^{156}$

\section{Large-Needle Aspiration biopsy (LNA)}

LNA is similar to FNA, the main difference being the use of a larger needle for aspiration. A 21-gauge 
needle is usually preferred. The sample is expelled into a tube instead of a glass slide. Finally the sample is processed for histological rather than cytological interpretation. ${ }^{123,157,158}$

More cellular material is aspirated with LNA, but the specimens are usually bloodier, which may interfere with the cytological interpretation. ${ }^{159}$ Moreover, it is more painful compared to FNA and more traumatic to cells and tissues. It may provide qualitatively superior smears compared to FNA, but it is not diagnostic in a greater number of cases. ${ }^{159}$ LNA is recommended by some authors as a repeat biopsy method for nodules that remain nondiagnostic after a repeat FNA. It can retrieve a diagnostic specimen in more than $80 \%$ of the nodules reinvestigated compared to $50-60 \%$ for repeat FNA. ${ }^{157}$

\section{Core-Needle Biopsy (CNB)}

Thyroid core of tissue for histological interpretation may also be obtained by CNB, using TruCut or Vim-Silverman needles. Local lidocaine anesthesia is necessary ${ }^{84,160} \mathrm{CNB}$ provides a larger tissue sample that retains its cellular architecture and may enable a more precise histological diagnosis, but it is not used in the routine assessment of thyroid nodules. This is due to the perceived risk of complications (mainly postbiopsy haematomas and pain) as well as the ear- lier success of FNA. Another disadvantage of CNB is that only one or two cores (from one or two sites) are usually obtained and thus the risk of sampling error is higher than that of FNA..$^{84,161,162}$

There is much controversy over the distinct role and efficacy of CNB in the management of thyroid nodules. Some authors have reported that CNB shows no advantage over FNA and it is also less acceptable by patients. ${ }^{163}$ Others consider that the two methods may be complementary and suggest that combined FNA and CNB should more accurately diagnose thyroid carcinomas. ${ }^{129,161}$ Finally, some authors consider that US-guided CNB is of high diagnostic yield and accuracy and it frequently obviates surgery in patients whose findings after FNA are recurrently nondiagnostic. ${ }^{162}$

\section{Step 5: Therapeutic approach (Figure 1)}

The therapeutic decision should be based upon the cytological result always in conjunction with the clinical and US findings.

\section{Benign cytology}

Even if the cytological interpretation indicates a benign nodule, all patients whose nodules are of clinically high suspicion for malignancy require surgical treatment. ${ }^{54}$

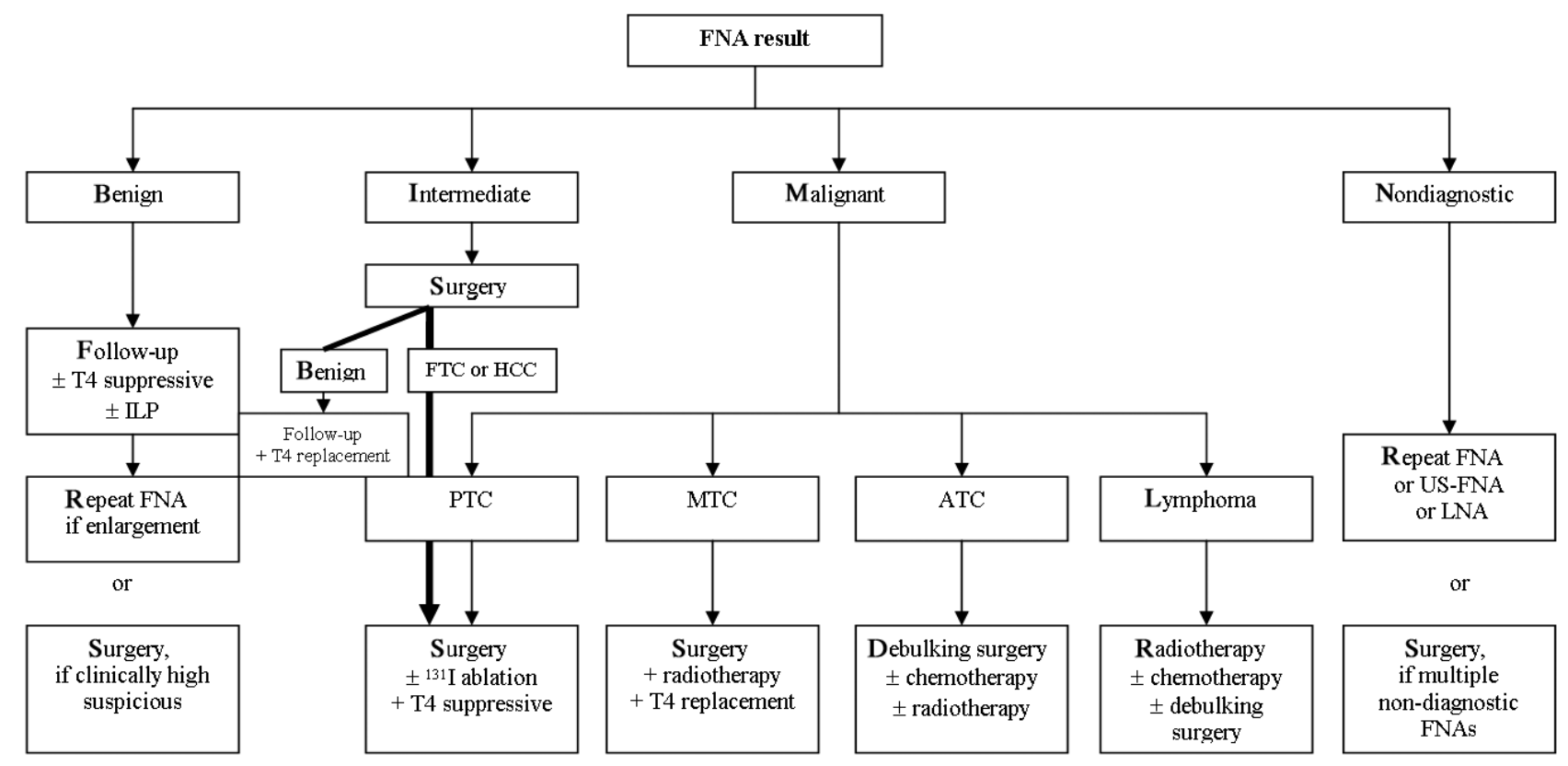

Figure 1. From FNA cytology to treatment guidelines. 
In cases of low clinical suspicion for malignancy and benign cytological results, the patients need a strict follow-up at 6 to18 month intervals because of the non-negligible false-negative rate of 5\% in FNA due to sampling error. ${ }^{1,54,133}$ Benign thyroid nodules may slowly increase in size. Although an increase in nodule volume by itself is not a reliable predictor of malignancy, ${ }^{164}$ in any case of nodule enlargement there is an indication for repeating FNA. ${ }^{1,165}$ Therefore, it is recommended that serial US be used in the followup of thyroid nodules to confirm clinically significant changes in size. One reasonable definition of enlargement is an increase of $20 \%$ in nodule diameter with a minimum increase in two or more dimensions of at least $2 \mathrm{~mm}$. Repeat FNA should be reserved for these nodules. The false-negative rate for benign thyroid nodules on the repeat FNA is low. ${ }^{1,166}$

The effectiveness of medical treatment of benign nodule(s) with L-thyroxine at TSH suppressive doses remains controversial. It has been used for years to prevent or reduce growth of thyroid nodules. ${ }^{62,167}$ Generally, there is a trend towards a reduction in volume of more than $50 \%$ of benign thyroid nodules, albeit without achieving statistical significance. ${ }^{167}$ Some studies have reported that L-thyroxine suppressive therapy results in reduction in nodule volume, especially in small ones, ${ }^{168-171}$ whereas others do not support this finding and suggest that patients with cytologically benign nodules are best followed without thyroxine treatment. ${ }^{165,172}$ Moreover, in a 10 -year retrospective analysis, $13 \%$ of histologically (after surgery) proved PTCs had previously shown a decrease in size during suppressive L-thyroxine therapy. ${ }^{173}$ Furthermore, significant adverse events should be considered, such as aggravation of angina in patients with coronary heart disease, atrial fibrillation and bone mass decrease, which are encountered especially in older patients. ${ }^{174-178}$ Therefore, suppressive therapy is not routinely recommended, ${ }^{1}$ but only after careful risk-benefit assessment. ${ }^{62}$ It seems that young healthy patients with relatively small thyroid nodules could benefit the most. ${ }^{58}$ In cases of nodule enlargement despite suppressive therapy, it is advised that suppressive therapy stop and the patient undergo surgery to exclude carcinoma. ${ }^{165}$

Moreover, it has been reported that US-guided ethanol sclerotherapy is a safe and effective tool for the therapy of benign thyroid cystic or mixed nodules, although repeated injections may be painful and there is always doubt about the benign or malignant nature of nodules even after a benign cytological result. ${ }^{179-181}$

In addition, interstitial laser photocoagulation (ILP) has recently been proposed as an alternative therapeutic procedure for the ablation of cytologically benign nodules causing cosmetic and/or pressure symptoms. ${ }^{182-186}$ Under sterile conditions and continuous US-guidance, a laser fiber is positioned in the thyroid nodule through the lumen of a spinal needle ( 21 or 22 gauge) and preceded by local anesthesia. Patients are treated with an output power of 2.5-3.5 W, dependent on the pretreatment nodule volume and the position of the nodule. There is a trend towards reducing the energy delivered (Joule/ $\mathrm{ml}$ of nodule volume). ${ }^{187}$ It is reported to be a safe and effective procedure performed on an outpatient basis. ${ }^{182-186,188}$ ILP approximately halves thyroid nodule volume within one month with concomitant symptom relief. ${ }^{182-186,188}$ The nodule volume reduction is comparable to that obtained following percutaneous ethanol injection, ${ }^{180,181}$ and the only side effect reported has been slight discomfort and moderate pain for a few days. ${ }^{184}$ The result seems not to be further improved after repeated sessions of ILP and therefore repeated sessions should be limited to selected patients with either larger nodules or to those with limited nodule reduction after the first session. ${ }^{188}$

\section{Malignant cytology}

Surgical resection in order to achieve local disease control remains the cornerstone of primary treatment for most thyroid malignancies, and is often followed by adjuvant radioiodine treatment for the papillary and follicular types of disease. Thyroid hormone suppressive therapy is used, as there is evidence which suggests that suppression of TSH prevents disease recurrence in patients with PTC, whereas treatment for progressive metastatic disease is often of limited benefit. ${ }^{189}$

Surgery for thyroid cancer should be performed by experienced surgeons involved in multidisciplinary teams, trained specifically in thyroid cancer surgery and performing a large number of thyroid cancer operations annually, including both primary as well as reoperative cases. ${ }^{38}$ 
In cases of PTC, it is recommended that the patient undergo extensive initial surgery such as total thyroidectomy (removal of all visible thyroid tissue) or near-total thyroidectomy (a small amount of thyroid tissue adjacent to the recurrent laryngeal nerve is left), if the carcinoma is more than $1 \mathrm{~cm}$ in size, multicentric, locally invasive, regionally metastatic, distantly metastatic, of poorly differentiated histotypes or if the age of the patient is over 40 or under 25 at the time of diagnosis. ${ }^{38,190-193}$ This aggressive approach seems to decrease tumor recurrence and overall mortality and, if performed by an experienced surgeon, the risk of adverse events (hypoparathyroidism and recurrent laryngeal nerve injury) is minimal. ${ }^{191,194}$

In the case of an intrathyroidal papillary carcinoma smaller than $1 \mathrm{~cm}$ in size without cervical nodal or distant metastases and without history of previous radiation exposure, thyroid lobectomy alone may be sufficient, ${ }^{1,38}$ although rates of recurrence are reduced by total or near-total thyroidectomy even among these low-risk patients. ${ }^{192,195}$

Although microscopic neck lymph node metastases are present at the time of diagnosis in $20-90 \%$ of patients with PTC, ${ }^{196}$ extensive lymph node dissection remains controversial. Some authors consider that bilateral central node dissection may result in better survival and a lower recurrence rate and that proper surgical technique and strategy can positively influence the survival of patients with PTC carcinoma. ${ }^{197,198}$ Other authors believe that it offers no advantage and may increase morbidity in patients with PTC. ${ }^{196}$ As non-visible affected nodes seem to respond to postoperative radioiodine ablation, preventive dissection may not improve long-term survival rates for these patients. ${ }^{197}$ Therefore, it is suggested that node dissection be considered for patients with macroscopically affected nodes or with lymph nodes detected in preoperative high-quality US. ${ }^{196,199}$

Initial surgery can be selectively supplemented with postoperative radioiodine $\left({ }^{131} \mathrm{I}\right)$ remnant ablation in an attempt to reduce locoregional recurrence risk. ${ }^{200}$ Ablation destroys residual thyroid tissue after thyroidectomy. The value, however, of postoperative radioiodine in preventing either nodal recurrence or cancer death in patients with PTC (and FTC) remains controversial because of its favorable prognosis and the risk of leukaemia from the radioiodine. Moreover, no randomized control trials have been performed to examine this issue. ${ }^{196,201,202}$ Retrospective studies have reported that ablation may be associated with significant reduction in recurrence and long-term specific mortality, ${ }^{190,191,201,203}$ especially for carcinomas that are larger than $1.5 \mathrm{~cm}$, multicentric, locally invasive, regionally metastatic or after incomplete tumor resection. ${ }^{190,200}$ In low-risk patients as defined by score systems MACIS (distant Metastasis, Age, Completeness of resection, local Invasion and Size) or AMES (patient Age, Metastases, Extent of resection, tumor Size) or TNM (Tumor-Node-Metastasis), remnant ablation seems not to have substantially improved the already excellent outcome of PTC patients after near-total thyroidectomy and conservative nodal excision. ${ }^{192,195,200}$ The optimal dose of radioiodine remains uncertain, but repeated $30 \mathrm{mCi}$ have been considered adequate for most thyroid remnant ablations, ${ }^{204}$ while it has been suggested that low radioiodine doses (29 to $50 \mathrm{mCi}$ ) were as effective as high doses (51 to 200 $\mathrm{mCi}$ ) in controlling tumor recurrence. ${ }^{190}$ Alternatively, it has been reported that US-guided percutaneous ethanol injection is an efficient treatment for patients with limited cervical nodal metastases from PTC who are not amenable to further surgical or radioiodine therapy. ${ }^{205}$

Finally, as well-differentiated thyroid carcinomas express TSH-receptors on the cell membrane, longterm L-thyroxine therapy following initial therapy, which aims at the suppression of TSH, appears justified. The benefit of suppressive therapy seems to be evident in high-risk patients, whereas it remains controversial in low-risk patients, ${ }^{206,207}$ especially considering the adverse effects of TSH suppression, as described above. ${ }^{174-178}$ Thus, initial TSH suppression below $0.1 \mathrm{mU} / \mathrm{L}$ is recommended for high-risk patients with thyroid carcinoma, while maintenance of the TSH slightly below the lower limit of normal $(0.1-0.5 \mathrm{mU} / \mathrm{L})$ is appropriate for low-risk patients. ${ }^{1,38}$ The use of T3 has no place in the long-term treatment of thyroid cancer patients. ${ }^{38}$

In the case of MTC, the patient can be cured strictly by complete resection of the thyroid tumor and neck metastases. Therefore, total thyroidectomy with central and complete bilateral neck dissection should be performed routinely in all patients with 
sporadic or familal MTC, even in those with small thyroid tumors, because nodal metastases seem to increase the risk of cause-specific mortality and the number of lymph node metastases is considered to adversely affect the biological cure after surgery. ${ }^{196,208}$ A contralateral neck dissection may be avoided only in cases of sporadic disease with unilateral involvement of the thyroid gland and absence of central and ipsilateral neck involvement. ${ }^{208}$ Postoperative radiotherapy is reported to optimise tumor control. ${ }^{209}$ After surgery, the patient should receive L-thyroxine at a dose sufficient to achieve euthyroidism. A suppressive dose is of no value, as C-cells are not TSH-responsive. Similarly, radioiodine ablation as an adjunct to surgery is of no value in the management of MTC, as the tumor cells do not absorb iodine..$^{210}$

For patients with MTC and residual or recurrent disease after primary surgery or for those with distant metastases, chemotherapy has usually resulted in partial responses. When a combination of drugs was used, the responses achieved were superior to those achieved with single-agent chemotherapy. ${ }^{211}$ In families with hereditary MTC, early preclinical diagnosis and intervention based on genetic testing might prevent poor disease outcome. ${ }^{189}$

In the case of ATC, an aggressive attempt at maximal tumor debulking followed by adjuvant chemotherapy and radiotherapy has been found to be of some value in patients with localized ATC, but it usually appears to be of limited benefit. On the other hand, there is no effective therapy for advanced or metastatic ATC and the disease is uniformly fatal. The outlook for patients with ATC remains grim and novel treatments are needed. ${ }^{47,189,212}$

Lymphoma of the thyroid may constitute a primary disease or may involve the gland as part of a systemic disease. Primary thyroid lymphoma is nearly always of the non-Hodgkin's type and it is not usually suspected before surgery or FNA. ${ }^{47}$ It is strongly associated with previously diagnosed Hashimoto's thyroitis, which means that it usually arises in a patient with preexisting Hashimoto's thyroiditis. ${ }^{213}$ The role of surgery is limited and, apart from debulking, aggressive surgical resections are not recommended. ${ }^{214}$ Radiotherapy alone is recommended for disease limited to the thyroid with or without cervical lymphadenopathy and small tumor volume. Results for patients with mediastinal extensions were unsatisfactory and the addition of combination chemotherapy is indicated in these patients..$^{47,215}$

\section{Indeterminate or suspicious cytology}

In the case of suspicious or indeterminate FNA results, most authors suggest that the patient should undergo lobectomy (as an initial approach), near-total or total thyroidectomy because of the possibility of capsular or vascular invasion and the uncertain natural history of these nodules. ${ }^{43,151,152,216}$ Ten to twenty per cent of all excised suspicious biopsies are carcinomas, while the rest (80-90\%) are adenomas. In the case of an adenoma, replacement therapy with L-thyroxine should be administered. In the case of FTC or HCC, the therapeutic recommendations are the same as described above for PTC (malignant cytology). If lobectomy was the initial approach, the patient should undergo complete thyroidectomy. ${ }^{217,218}$ If the lymph nodes are suspected for metastasis, although this is rare in FTC, they should be dissected as well, as it may adversely affect cause-specific mortality. ${ }^{196,219}$

During the last decade, many studies have searched for predictors of malignancy for indeterminate cytology to avoid unnecessary thyroidectomy. It has been reported that among those patients, clinical findings associated with a malignant nodule were: diameter larger than $3 \mathrm{~cm}$, fixation of the mass and young age. ${ }^{220-222}$ Therefore, strict follow-up every 6 months (with US and repeat FNA, if necessary) may be more appropriate for older patients with small, mobile, indeterminate nodules or those at high risk for surgery. In such individuals, surgery is rendered unavoidable if the nodule enlarges. ${ }^{221,222}$ At immunohistochemical level, the most promising predictors seem to be the detection of galectin-3 and the HBME-1 monoclonal antibody, which both have been strongly related to malignant thyroid cells. ${ }^{223,224}$

Single Hürthle cells can also be found in Hashimoto's thyroiditis and in degenerating adenomas. However, thyroidectomy is not recommended in these patients. ${ }^{58,225}$

\section{Non-diagnostic biopsies}

Nondiagnostic biopsies need to be repeated and, if they were conducted using the conventional FNA, 
LNA $^{157}$ or US-FNA is the next logical step, ${ }^{226}$ because it is suggested that US-FNA allows a more precise and adequate sampling and is associated with a lower rate of false-negative results. ${ }^{132}$ Nevertheless, some nodules, particularly the cystic, continue to yield nondiagnostic cytological results despite repeated biopsies. As they may be associated with a high probability of thyroid malignancy, meticulous follow-up or surgical excision is required. ${ }^{1,85,134,227}$ Surgery should be strongly recommended if the cytologically nondiagnostic nodule is solid. ${ }^{1}$

\section{REFERENCES}

1. Cooper DS, Doherty GM, Haugen BR, et al, 2006 Management guidelines for patients with thyroid nodules and differentiated thyroid cancer. Thyroid 16: 109-142.

2. Hegedus L, 2004 Clinical practice. The thyroid nodule. N Engl J Med 351: 1764-1771.

3. Lin JD, Chao TC, Huang BY, Chen ST, Chang HY, Hsueh C, 2005 Thyroid cancer in the thyroid nodules evaluated by ultrasonography and fine-needle aspiration cytology. Thyroid 15: 708-717.

4. Werk EE Jr, Vernon BM, Gonzalez JJ, Ungaro PC, McCoy RC, 1984 Cancer in thyroid nodules. A community hospital survey. Arch Intern Med 144: 474-476.

5. Gharib H, Goellner JR, 1993 Fine-needle aspiration biopsy of the thyroid: an appraisal. Ann Intern Med 118: 282-289.

6. Vander JB, Gaston EA, Dawber TR, 1968 The significance of nontoxic thyroid nodules. Final report of a 15-year study of the incidence of thyroid malignancy. Ann Intern Med 69: 537-540.

7. Tunbridge WM, Evered DC, Hall R, et al, 1977 The spectrum of thyroid disease in a community: the Whickham survey. Clin Endocrinol (Oxf) 7: 481-493.

8. Brander A, Viikinkoski P, Tuuhea J, Voutilainen L, Kivisaari L, 1992 Clinical versus ultrasound examination of the thyroid gland in common clinical practice. J Clin Ultrasound 20: 37-42.

9. Schneider AB, Bekerman C, Leland J, et al, 1997 Thyroid nodules in the follow-up of irradiated individuals: comparison of thyroid ultrasound with scanning and palpation. J Clin Endocrinol Metab 82: 4020-4027.

10. Wong CK, Wheeler MH, 2000 Thyroid nodules: rational management. World J Surg 24: 934-941.

11. Landis SH, Murray T, Bolden S, Wingo PA, 1998 Cancer statistics, 1998. CA Cancer J Clin 48: 6-29.

12. Carroll BA, 1982 Asymptomatic thyroid nodules: incidental sonographic detection. AJR Am J Roentgenol 138: 499-501.

13. Brander A, Viikinkoski P, Nickels J, Kivisaari L, 1991 Thyroid gland: US screening in a random adult population. Radiology 181: 683-687.

14. Ezzat S, Sarti DA, Cain DR, Braunstein GD, 1994 Thyroid incidentalomas. Prevalence by palpation and ultrasonography. Arch Intern Med 154: 1838-1840.

15. Tan GH, Gharib H, 1997 Thyroid incidentalomas: management approaches to nonpalpable nodules discovered incidentally on thyroid imaging. Ann Intern Med 126: 226-231.

16. Rice CO, 1932 Incidence of nodules in the thyroid. Arch Surg 505-529.

17. Mortensen JD, Woolner LB, Bennett WA, 1955 Gross and microscopic findings in clinically normal thyroid glands. J Clin Endocrinol Metab 15: 1270-1280.

18. Wang C, Crapo LM, 1997 The epidemiology of thyroid disease and implications for screening. Endocrinol Metab Clin North Am 26: 189-218.

19. Schneider AB, Shore-Freedman E, Ryo UY, Bekerman C, Favus M, Pinsky S, 1985 Radiation-induced tumors of the head and neck following childhood irradiation. Prospective studies. Medicine (Baltimore) 64: 1-15.

20. Belfiore A, La Rosa GL, La Porta GA, et al, 1992 Cancer risk in patients with cold thyroid nodules: relevance of iodine intake, sex, age, and multinodularity. Am J Med 93: 363-369.

21. McHenry C, Smith M, Lawrence AM, Jarosz H, Paloyan E, 1988 Nodular thyroid disease in children and adolescents: a high incidence of carcinoma. Am Surg 54: 444-447.

22. Pazaitou-Panayiotou K, Kaprara A, Boudina M, et al, 2005 Thyroid carcinoma in children and adolescents: presentation, clinical course, and outcome of therapy in 23 children and adolescents in Northern Greece. Hormones (Athens) 4: 213-220.

23. Tuttle RM, Lemar H, Burch HB, 1998 Clinical features associated with an increased risk of thyroid malignancy in patients with follicular neoplasia by fine-needle aspiration. Thyroid 8: 377-383.

24. Kumar H, Daykin J, Holder R, Watkinson JC, Sheppard MC, Franklyn JA, 1999 Gender, clinical findings, and serum thyrotropin measurements in the prediction of thyroid neoplasia in 1005 patients presenting with thyroid enlargement and investigated by fine-needle aspiration cytology. Thyroid 9: 1105-1109.

25. Schneider AB, 1990 Radiation-induced thyroid tumors. Endocrinol Metab Clin North Am 19: 495-508.

26. Lairmore TC, Wells SA Jr, 1991 Medullary carcinoma of the thyroid: current diagnosis and management. Semin Surg Oncol 7: 92-99.

27. Belfiore A, Giuffrida D, La Rosa GL, et al, 1989 High frequency of cancer in cold thyroid nodules occurring at young age. Acta Endocrinol (Copenh) 121: 197-202.

28. Hay ID, Grant CS, Taylor WF, McConahey WM, 1987 Ipsilateral lobectomy versus bilateral lobar resection in papillary thyroid carcinoma: a retrospective analysis of surgical outcome using a novel prognostic scoring system. Surgery 102: 1088-1095.

29. Sisson JC, 1989 Medical treatment of benign and malignant thyroid tumors. Endocrinol Metab Clin North Am 18: 359-387.

30. Kim WB, Han SM, Kim TY, et al, 2004 Ultrasonographic screening for detection of thyroid cancer in patients with Graves' disease. Clin Endocrinol (Oxf) 60: 719-725.

31. Ortiz R, Hupart KH, DeFesi CR, Surks MI, 1998 Effect 
of early referral to an endocrinologist on efficiency and cost of evaluation and development of treatment plan in patients with thyroid nodules. J Clin Endocrinol Metab 83: 3803-3807.

32. Cerise EJ, Randall S, Ochsner A, 1952 Carcinoma of the thyroid and nontoxic nodular goiter. Surgery 31: 552-561.

33. Franklyn JA, Daykin J, Young J, Oates GD, Sheppard MC, 1993 Fine needle aspiration cytology in diffuse or multinodular goitre compared with solitary thyroid nodules. BMJ 307: 240-

34. Tollin SR, Mery GM, Jelveh N, et al, 2000 The use of fine-needle aspiration biopsy under ultrasound guidance to assess the risk of malignancy in patients with a multinodular goiter. Thyroid 10: 235-241.

35. Gandolfi PP, Frisina A, Raffa M, et al, 2004 The incidence of thyroid carcinoma in multinodular goiter: retrospective analysis. Acta Biomed Ateneo Parmense 75: 114-117.

36. McCall A, Jarosz H, Lawrence AM, Paloyan E, 1986 The incidence of thyroid carcinoma in solitary cold nodules and in multinodular goiters. Surgery 100: 1128-1132.

37. Marqusee E, Benson CB, Frates MC, et al, 2000 Usefulness of ultrasonography in the management of nodular thyroid disease. Ann Intern Med 133: 696-700.

38. Pacini F, Schlumberger M, Dralle H, Elisei R, Smit JW, Wiersinga W, 2006 European consensus for the management of patients with differentiated thyroid carcinoma of the follicular epithelium. Eur J Endocrinol 154: 787-803.

39. Salabe GB, 2001 Pathogenesis of thyroid nodules: histological classification? Biomed Pharmacother 55: 39-53.

40. Aslaner A, Aydin M, Ozdere A, 2005 Multinodular goitre with thyroid hemiagenesis: a case report and review of the literature. Acta Chir Belg 105: 528-530.

41. Clark OH, Okerlund MD, Cavalieri RR, Greenspan FS, 1979 Diagnosis and treatment of thyroid, parathyroid, and thyroglossal duct cysts. J Clin Endocrinol Metab 48: 983-988.

42. Goldstein N, Layfield LJ, 1991 Thyromegaly secondary to simultaneous papillary carcinoma and histiocytosis X. Report of a case and review of the literature. Acta Cytol 35: 422-426.

43. Gosain AK, Clark OH, 1984 Hurthle cell neoplasms. Malignant potential. Arch Surg 119: 515-519.

44. Harada T, Ito Y, Shimaoka K, Taniguchi T, Matsudo A, Senoo T, 1980 Clinical evaluation of 201thallium chloride scan for thyroid nodule. Eur J Nucl Med 5: 125-130.

45. Nishihara E, Miyauchi A, Matsuzuka F, et al, 2005 Acute suppurative thyroiditis after fine-needle aspiration causing thyrotoxicosis. Thyroid 15: 1183-1187.

46. Ruggiero FP, Frauenhoffer E, Stack BC, Jr, 2005 Thyroid lymphoma: a single institution's experience. Otolaryngol Head Neck Surg 133: 888-896.

47. Samaan NA, Ordonez NG, 1990 Uncommon types of thyroid cancer. Endocrinol Metab Clin North Am 19: 637-648

48. Shabb NS, Salti I, 2006 Subacute thyroiditis: fine-needle aspiration cytology of 14 cases presenting with thyroid nodules. Diagn Cytopathol 34: 18-23.
49. Shanks JH, Harris M, Howat AJ, Freemont AJ, 1997 Angiotropic lymphoma with endocrine involvement. Histopathology 31: 161-166.

50. Tsang K, Duggan MA, 1992 Vascular proliferation of the thyroid. A complication of fine-needle aspiration. Arch Pathol Lab Med 116: 1040-1042.

51. Scopa CD, 2004 Histopathology of Thyroid Tumors. An Overview. Hormones (Athens) 3: 100-110.

52. Terzidis K, Tourli P, Kiapekou E, Alevizaki M, 2007 Thyroid tuberculosis. Hormones (Athens) 6: 75-79.

53. Malandrinou F, Tseleni-Balafouta S, Kakaviatos N, Singhellakis P, 2002 Primary malignant fibrous histiocytoma on the thyroid. Hormones (Athens) 1: 255-259.

54. Hamming JF, Goslings BM, van Steenis GJ, van Ravenswaay CH, Hermans J, 1990 The value of fine-needle aspiration biopsy in patients with nodular thyroid disease divided into groups of suspicion of malignant neoplasms on clinical grounds. Arch Intern Med 150: 113-116.

55. Mazzaferri EL, de los Santos ET, Rofagha-Keyhani S, 1988 Solitary thyroid nodule: diagnosis and management. Med Clin North Am 72: 1177-1211.

56. Mazzaferri EL, 1993 Management of a solitary thyroid nodule. N Engl J Med 328: 553-559.

57. Ashcraft MW, Van Herle AJ, 1981 Management of thyroid nodules. I: History and physical examination, blood tests, X-ray tests, and ultrasonography. Head Neck Surg 3: 216-230.

58. Garber JR, 2006 Thyroid nodules 2006: managing what has been known for over 50 years. Hormones (Athens) 5: 179-186.

59. McConahey WM, Hay ID, Woolner LB, van Heerden JA, Taylor WF, 1986 Papillary thyroid cancer treated at the Mayo Clinic, 1946 through 1970: initial manifestations, pathologic findings, therapy, and outcome. Mayo Clin Proc 61: 978-996.

60. Yokozawa T, Miyauchi A, Kuma K, Sugawara M, 1995 Accurate and simple method of diagnosing thyroid nodules the modified technique of ultrasound-guided fine needle aspiration biopsy. Thyroid 5: 141-145.

61. Boelaert K, Horacek J, Holder RL, Watkinson JC, Sheppard MC, Franklyn JA, 2006 Serum thyrotropin concentration as a novel predictor of malignancy in thyroid nodules investigated by fine-needle aspiration. J Clin Endocrinol Metab 91: 4295-4301.

62. Castro MR, Gharib H, 2005 Continuing controversies in the management of thyroid nodules. Ann Intern Med 142: 926-931.

63. Zagorianakou P, Malamou-Mitsi V, Zagorianakou N, Stefanou D, Tsatsoulis A, Agnantis NJ, 2005 The role of fine-needle aspiration biopsy in the management of patients with thyroid nodules. In Vivo 19: 605-609.

64. Horvit PK, Gagel RF, 1997 The goitrous patient with an elevated serum calcitonin--what to do? J Clin Endocrinol Metab 82: 335-337.

65. Niccoli P, Wion-Barbot N, Caron P, et al, 1997 Interest of routine measurement of serum calcitonin: study in a large series of thyroidectomized patients. The French Medullary Study Group. J Clin Endocrinol Metab 82: 
338-341.

66. Pacini F, Fontanelli M, Fugazzola L, et al, 1994 Routine measurement of serum calcitonin in nodular thyroid diseases allows the preoperative diagnosis of unsuspected sporadic medullary thyroid carcinoma. J Clin Endocrinol Metab 78: 826-829.

67. Vierhapper H, Raber W, Bieglmayer C, Kaserer K, Weinhausl A, Niederle B, 1997 Routine measurement of plasma calcitonin in nodular thyroid diseases. J Clin Endocrinol Metab 82: 1589-1593.

68. Hodak SP, Burman KD, 2004 The calcitonin conundrum --is it time for routine measurement of serum calcitonin in patients with thyroid nodules? J Clin Endocrinol Metab 89: 511-514.

69. Bennedbaek FN, Hegedus L, 2000 Management of the solitary thyroid nodule: results of a North American survey. J Clin Endocrinol Metab 85: 2493-2498.

70. Pacini F, Pinchera A, Giani C, Grasso L, Doveri F, Baschieri L, 1980 Serum thyroglobulin in thyroid carcinoma and other thyroid disorders. J Endocrinol Invest 3: 283292.

71. Fujimoto Y, Oka A, Omoto R, Hirose M, 1967 Ultrasound scanning of the thyroid gland as a new diagnostic approach. Ultrasonics 5: 177-180.

72. Clark KJ, Cronan JJ, Scola FH, 1995 Color Doppler sonography: anatomic and physiologic assessment of the thyroid. J Clin Ultrasound 23: 215-223.

73. Haber RS, 2000 Role of ultrasonography in the diagnosis and management of thyroid cancer. Endocr Pract 6: 396400.

74. Hegedus L, 2001 Thyroid ultrasound. Endocrinol Metab Clin North Am 30: 339-3ix.

75. Renard E, Jaffiol C, Rouanet JP, Lamarque JL, 1990 [New techniques of thyroid medical imaging. Value and limitations in the exploration of isolated thyroid nodules]. Ann Endocrinol (Paris) 51: 155-160.

76. Solbiati L, Volterrani L, Rizzatto G, et al, 1985 The thyroid gland with low uptake lesions: evaluation by ultrasound. Radiology 155: 187-191.

77. Radecki PD, Arger PH, Arenson RL, et al, 1984 Thyroid imaging: comparison of high-resolution real-time ultrasound and computed tomography. Radiology 153: 145-147.

78. Crile G Jr, 1966 Treatment of thyroid cysts by aspiration. Surgery 59: 210-212.

79. Miller JM, Zafar SU, Karo JJ, 1974 The cystic thyroid nodule. Recognition and management. Radiology 110: 257-261.

80. Ma MK, Ong GB, 1975 Cystic thyroid nodules. Br J Surg 62: 205-206.

81. Rosen IB, Provias JP, Walfish PG, 1986 Pathologic nature of cystic thyroid nodules selected for surgery by needle aspiration biopsy. Surgery 100: 606-613.

82. Walfish PG, Hazani E, Strawbridge HT, Miskin M, Rosen IB, 1977 Combined ultrasound and needle aspiration cytology in the assessment and management of hypofunctioning thyroid nodule. Ann Intern Med 87: 270-274.
83. Hammer M, Wortsman J, Folse R, 1982 Cancer in cystic lesions of the thyroid. Arch Surg 117: 1020-1023.

84. Ashcraft MW, Van Herle AJ, 1981 Management of thyroid nodules. II: Scanning techniques, thyroid suppressive therapy, and fine needle aspiration. Head Neck Surg 3: 297-322.

85. de los Santos ET, Keyhani-Rofagha S, Cunningham JJ, Mazzaferri EL, 1990 Cystic thyroid nodules. The dilemma of malignant lesions. Arch Intern Med 150: 1422-1427.

86. Melliere D, Massin JP, Calmettes C, Chigot JP, Savoie JC, Arnier H, 1970 [The risk of malignancy in cold thyroid nodules. 607 operated cases]. Presse Med 78: 311-314.

87. La Rosa GL, Belfiore A, Giuffrida D, et al, 1991 Evaluation of the fine needle aspiration biopsy in the preoperative selection of cold thyroid nodules. Cancer 67: 2137-2141.

88. Levine RA, 2004 Something old and something new: a brief history of thyroid ultrasound technology. Endocr Pract 10: 227-233.

89. Rago T, Vitti P, Chiovato L, et al, 1998 Role of conventional ultrasonography and color flow-doppler sonography in predicting malignancy in "cold" thyroid nodules. Eur J Endocrinol 138: 41-46.

90. Varverakis E, Neonakis E, 2002 Contribution of highresolution ultrasonography in the differential diagnosis of benign from malignant thyroid nodules. Hormones (Athens) 1: 51-56.

91. Cochand-Priollet B, Guillausseau PJ, Chagnon S, et al, 1994 The diagnostic value of fine-needle aspiration biopsy under ultrasonography in nonfunctional thyroid nodules: a prospective study comparing cytologic and histologic findings. Am J Med 97: 152-157.

92. Weber AL, Randolph G, Aksoy FG, 2000 The thyroid and parathyroid glands. CT and MR imaging and correlation with pathology and clinical findings. Radiol Clin North Am 38: 1105-1129.

93. Hagag P, Strauss S, Weiss M, 1998 Role of ultrasoundguided fine-needle aspiration biopsy in evaluation of nonpalpable thyroid nodules. Thyroid 8: 989-995.

94. Iannuccilli JD, Cronan JJ, Monchik JM, 2004 Risk for malignancy of thyroid nodules as assessed by sonographic criteria: the need for biopsy. J Ultrasound Med 23: 14551464.

95. Kakkos SK, Scopa CD, Chalmoukis AK, et al, 2000 Relative risk of cancer in sonographically detected thyroid nodules with calcifications. J Clin Ultrasound 28: 347-352.

96. Rausch P, Nowels K, Jeffrey RB Jr, 2001 Ultrasonographically guided thyroid biopsy: a review with emphasis on technique. J Ultrasound Med 20: 79-85.

97. Varverakis E, Neonakis E, Tzardi M, Chrysos E, 2007 Role of color Doppler ultrasonography in the preoperative management of cold thyroid nodules. Hormones (Athens) 6: 44-51.

98. Bonnema SJ, Bennedbaek FN, Ladenson PW, Hegedus L, 2002 Management of the nontoxic multinodular goiter: a North American survey. J Clin Endocrinol Metab 87: 112-117. 
99. Hays MT, Wesselossky B, 1973 Simultaneous measurement of thyroidal trapping (99mTcO4-) and binding ( $\left.{ }^{131} \mathrm{I}-\right)$ : clinical and experimental studies in man. $\mathrm{J}$ Nucl Med 14: 785-792.

100. Reschini E, Catania A, Ferrari C, Bergonzi M, Paracchi A, Raineri P, 1993 Comparison of pertechnetate and radioiodine thyroid scintiscans in thyroid disease. $\mathrm{J}$ Nucl Biol Med 37: 12-17.

101. Ramos CD, Zantut-Wittmann DE, Tambascia MA, Assumpcao L, Etchebehere EC, Camargo EE, 2000 Thyroid suppression test with L-thyroxine and [99mTc] pertechnetate. Clin Endocrinol (Oxf) 52: 471-477.

102. McCaffrey TV, 2000 Evaluation of the thyroid nodule. Cancer Control 7: 223-228.

103. Nelson RL, Wahner HW, Gorman CA, 1978 Rectilinear thyroid scanning as a predictor of malignancy. Ann Intern Med 88: 41-44.

104. Abdel-Razzak M, Christie JH, 1979 Thyroid carcinoma in an autonomously functioning nodule. J Nucl Med 20: 1001-1002.

105. Khan O, Ell PJ, Maclennan KA, Kurtz A, Williams ES, 1981 Thyroid carcinoma in an autonomously hyperfunctioning thyroid nodule. Postgrad Med J 57: 172-175.

106. Hoving J, Piers DA, Vermey A, Oosterhuis JW, 1981 Carcinoma in hyperfunctioning thyroid nodule in recurrent hyperthyroidism. Eur J Nucl Med 6: 131-132.

107. Hayes FJ, Sheahan K, Heffernan A, McKenna TJ, 1996 Aggressive thyroid cancer associated with toxic nodular goitre. Eur J Endocrinol 134: 366-370.

108. dell'Erba L, Gerundini P, Caputo M, Bagnasco M, 2003 Association of hyperfunctioning thyroid adenoma with thyroid cancer presenting as «trapping only» nodule at 99mTcO4- scintigraphy. J Endocrinol Invest 26: 11241127.

109. Reschini E, Ferrari C, Castellani M, et al, 2006 The trapping-only nodules of the thyroid gland: prevalence study. Thyroid 16: 757-762.

110. Shambaugh GE 3rd, Quinn JL, Oyasu R, Freinkel N, 1974 Disparate thyroid imaging. Combined studies with sodium pertechnetate Tc $99 \mathrm{~m}$ and radioactive iodine. JAMA 228: 866-869.

111. Turner JW, Spencer RP, 1976 Thyroid carcinoma presenting as a pertechnetate «hot» nodule, but without ${ }^{131} \mathrm{I}$ uptake: case report. J Nucl Med 17: 22-23.

112. O’Connor MK, Cullen MJ, Malone JF, 1977 A kinetic study of [131I] iodide and [99mTc] pertechnetate in thyroid carcinoma to explain a scan discrepancy: case report. J Nucl Med 18: 796-798.

113. Erjavec M, Movrin T, Auersperg M, Golouh R, 1977 Comparative accumulation of $99 \mathrm{mTc}$ and $131 \mathrm{I}$ in thyroid nodules: case report. J Nucl Med 18: 346-347.

114. Arnold JE, Pinsky S, 1976 Comparison of 99mTc and 123I for thyroid imaging. J Nucl Med 17: 261-267.

115. Blum M, Goldman AB, 1975 Improved diagnosis of "nondelineated" thyroid nodules by oblique scintillation scanning and echography. J Nucl Med 16: 713-715.

116. Steinberg M, Cavalieri RR, Choy SH, 1970 Uptake of technetium 99-pertechnetate in a primary thyroid car- cinoma: need for caution in evaluating nodules. J Clin Endocrinol Metab 31: 81-84.

117. Schoder H, Yeung HW, 2004 Positron emission imaging of head and neck cancer, including thyroid carcinoma. Semin Nucl Med 34: 180-197.

118. Kang KW, Kim SK, Kang HS, et al, 2003 Prevalence and risk of cancer of focal thyroid incidentaloma identified by 18F-fluorodeoxyglucose positron emission tomography for metastasis evaluation and cancer screening in healthy subjects. J Clin Endocrinol Metab 88: 4100-4104.

119. Chen YK, Ding HJ, Chen KT, et al, 2005 Prevalence and risk of cancer of focal thyroid incidentaloma identified by 18F-fluorodeoxyglucose positron emission tomography for cancer screening in healthy subjects. Anticancer Res 25: $1421-1426$.

120. Castro MR, Gharib H, 2003 Thyroid fine-needle aspiration biopsy: progress, practice, and pitfalls. Endocr Pract 9: 128-136.

121. Chen HW, Tseng FY, Su DH, Chang YL, Chang TC, 2006 Secondary infection and ischemic necrosis after fine needle aspiration for a painful papillary thyroid carcinoma: a case report. Acta Cytol 50: 217-220.

122. Willems JS, Lowhagen T, 1981 Fine-needle aspiration cytology in thyroid disease. Clin Endocrinol Metab 10: 247-266.

123. Wu M, Burstein DE, 2004 Fine needle aspiration. Cancer Invest 22: 620-628.

124. Harsoulis P, Leontsini M, Economou A, Gerasimidis T, Smbarounis C, 1986 Fine needle aspiration biopsy cytology in the diagnosis of thyroid cancer: comparative study of 213 operated patients. Br J Surg 73: 461-464.

125. Gershengorn MC, McClung MR, Chu EW, Hanson TA, Weintraub BD, Robbins J, 1977 Fine-needle aspiration cytology in the preoperative diagnosis of thyroid nodules. Ann Intern Med 87: 265-269.

126. Miller JM, Hamburger JI, Kini SR, 1981 The needle biopsy diagnosis of papillary thyroid carcinoma. Cancer 48: 989-993.

127. Hall TL, Layfield LJ, Philippe A, Rosenthal DL, 1989 Sources of diagnostic error in fine needle aspiration of the thyroid. Cancer 63: 718-725.

128. Boey J, Hsu C, Collins RJ, Wong J, 1984 A prospective controlled study of fine-needle aspiration and Tru-cut needle biopsy of dominant thyroid nodules. World J Surg 8: 458-465.

129. Nishiyama RH, Bigos ST, Goldfarb WB, Flynn SD, Taxiarchis LN, 1986 The efficacy of simultaneous fine-needle aspiration and large-needle biopsy of the thyroid gland. Surgery 100: 1133-1137.

130. Jayaram G, 1985 Fine needle aspiration cytologic study of the solitary thyroid nodule. Profile of 308 cases with histologic correlation. Acta Cytol 29: 967-973.

131. Rosen IB, Wallace C, Strawbridge HG, Walfish PG, 1981 Reevaluation of needle aspiration cytology in detection of thyroid cancer. Surgery 90: 747-756.

132. Danese D, Sciacchitano S, Farsetti A, Andreoli M, Pontecorvi A, 1998 Diagnostic accuracy of conventional versus sonography-guided fine-needle aspiration biopsy 
of thyroid nodules. Thyroid 8: 15-21.

133. Carmeci C, Jeffrey RB, McDougall IR, Nowels KW, Weigel RJ, 1998 Ultrasound-guided fine-needle aspiration biopsy of thyroid masses. Thyroid 8: 283-289.

134. Chow LS, Gharib H, Goellner JR, van Heerden JA, 2001 Nondiagnostic thyroid fine-needle aspiration cytology: management dilemmas. Thyroid 11: 1147-1151.

135. Baskin HJ, 2004 Ultrasound-guided fine-needle aspiration biopsy of thyroid nodules and multinodular goiters. Endocr Pract 10: 242-245.

136. Leenhardt L, Hejblum G, Franc B, et al, 1999 Indications and limits of ultrasound-guided cytology in the management of nonpalpable thyroid nodules. J Clin Endocrinol Metab 84: 24-28.

137. Papini E, Guglielmi R, Bianchini A, et al, 2002 Risk of malignancy in nonpalpable thyroid nodules: predictive value of ultrasound and color-Doppler features. J Clin Endocrinol Metab 87: 1941-1946.

138. Roh JL, 2006 Intrathyroid hemorrhage and acute upper airway obstruction after fine needle aspiration of the thyroid gland. Laryngoscope 116: 154-156.

139. Noordzij JP, Goto MM, 2005 Airway compromise caused by hematoma after thyroid fine-needle aspiration. Am J Otolaryngol 26: 398-399.

140. Karwowski JK, Nowels KW, McDougall IR, Weigel RJ, 2002 Needle track seeding of papillary thyroid carcinoma from fine needle aspiration biopsy. A case report. Acta Cytol 46: 591-595.

141. Hales MS, Hsu FS, 1990 Needle tract implantation of papillary carcinoma of the thyroid following aspiration biopsy. Acta Cytol 34: 801-804.

142. Shinohara S, Yamamoto E, Tanabe M, Maetani T, Kim T, 2001 Implantation metastasis of head and neck cancer after fine needle aspiration biopsy. Auris Nasus Larynx 28: 377-380.

143. Vercelli-Retta J, Almeida E, Ardao G, et al, 1997 Capsular pseudoinvasion after fine-needle aspiration of follicular adenomas of the thyroid. Diagn Cytopathol 17: 295-297.

144. Axiotis CA, Merino MJ, Ain K, Norton JA, 1991 Papillary endothelial hyperplasia in the thyroid following fineneedle aspiration. Arch Pathol Lab Med 115: 240-242.

145. Pinto RG, Couto F, Mandreker S, 1996 Infarction after fine needle aspiration. A report of four cases. Acta Cytol 40: 739-741.

146. Jayaram G, Aggarwal S, 1989 Infarction of thyroid nodule: a rare complication following fine needle aspiration. Acta Cytol 33: 940-941.

147. Isenberg SF, 1994 Thyroid abscess resulting from fineneedle aspiration. Otolaryngol Head Neck Surg 111: $832-833$

148. Goellner JR, Gharib H, Grant CS, Johnson DA, 1987 Fine needle aspiration cytology of the thyroid, 1980 to 1986. Acta Cytol 31: 587-590.

149. MacDonald L, Yazdi HM, 1996 Nondiagnostic fine needle aspiration biopsy of the thyroid gland: a diagnostic dilemma. Acta Cytol 40: 423-428.

150. Ylagan LR, Farkas T, Dehner LP, 2004 Fine needle aspiration of the thyroid: a cytohistologic correlation and study of discrepant cases. Thyroid 14: 35-41.

151. Gharib H, Goellner JR, Zinsmeister AR, Grant CS, Van Heerden JA, 1984 Fine-needle aspiration biopsy of the thyroid. The problem of suspicious cytologic findings. Ann Intern Med 101: 25-28.

152. Block MA, Dailey GE, Robb JA, 1983 Thyroid nodules indeterminate by needle biopsy. Am J Surg 146: 72-78.

153. Mair S, Dunbar F, Becker PJ, Du PW, 1989 Fine needle cytology--is aspiration suction necessary? A study of 100 masses in various sites. Acta Cytol 33: 809-813.

154. Santos JE, Leiman G, 1988 Nonaspiration fine needle cytology. Application of a new technique to nodular thyroid disease. Acta Cytol 32: 353-356.

155. Braun H, Walch C, Beham A, Moinfar F, 1997 [Fine needle capillary cytology versus fine needle aspiration cytology--a comparison of quality between puncture techniques in the ENT area]. Laryngorhinootologie 76: 358-363.

156. Kamal MM, Arjune DG, Kulkarni HR, 2002 Comparative study of fine needle aspiration and fine needle capillary sampling of thyroid lesions. Acta Cytol 46: 30-34.

157. Carpi A, Sagripanti A, Nicolini A, et al, 1998 Large needle aspiration biopsy for reducing the rate of inadequate cytology on fine needle aspiration specimens from palpable thyroid nodules. Biomed Pharmacother 52: 303-307.

158. Mizukami Y, Michigishi T, Nonomura A, et al, 1996 Large needle biopsy of the thyroid gland. Anat Pathol 1: 99-138.

159. Tangpricha V, Chen BJ, Swan NC, Sweeney AT, de las MA, Safer JD, 2001 Twenty-one-gauge needles provide more cellular samples than twenty-five-gauge needles in fine-needle aspiration biopsy of the thyroid but may not provide increased diagnostic accuracy. Thyroid 11: 973-976.

160. Crile G Jr, Hawk WA Jr, 1973 Aspiration biopsy of thyroid nodules. Surg Gynecol Obstet 136: 241-245.

161. Liu Q, Castelli M, Gattuso P, Prinz RA, 1995 Simultaneous fine-needle aspiration and core-needle biopsy of thyroid nodules. Am Surg 61: 628-632.

162. Screaton NJ, Berman LH, Grant JW, 2003 US-guided core-needle biopsy of the thyroid gland. Radiology 226 : 827-832.

163. Pisani T, Bononi M, Nagar C, Angelini M, Bezzi M, Vecchione A, 2000 Fine needle aspiration and core needle biopsy techniques in the diagnosis of nodular thyroid pathologies. Anticancer Res 20: 3843-3847.

164. Alexander EK, Hurwitz S, Heering JP, et al, 2003 Natural history of benign solid and cystic thyroid nodules. Ann Intern Med 138: 315-318.

165. Gharib H, Mazzaferri EL, 1998 Thyroxine suppressive therapy in patients with nodular thyroid disease. Ann Intern Med 128: 386-394.

166. Brander AE, Viikinkoski VP, Nickels JI, Kivisaari LM, 2000 Importance of thyroid abnormalities detected at US screening: a 5-year follow-up. Radiology 215: 801-806.

167. Castro MR, Caraballo PJ, Morris JC, 2002 Effectiveness of thyroid hormone suppressive therapy in benign solitary 
thyroid nodules: a meta-analysis. J Clin Endocrinol Metab 87: 4154-4159.

168. La Rosa GL, Lupo L, Giuffrida D, Gullo D, Vigneri R, Belfiore A, 1995 Levothyroxine and potassium iodide are both effective in treating benign solitary solid cold nodules of the thyroid. Ann Intern Med 122: 1-8.

169. Lima N, Knobel M, Cavaliere H, Sztejnsznajd C, Tomimori E, Medeiros-Neto G, 1997 Levothyroxine suppressive therapy is partially effective in treating patients with benign, solid thyroid nodules and multinodular goiters. Thyroid 7: 691-697.

170. Wemeau JL, Caron P, Schvartz C, et al, 2002 Effects of thyroid-stimulating hormone suppression with levothyroxine in reducing the volume of solitary thyroid nodules and improving extranodular nonpalpable changes: a randomized, double-blind, placebo-controlled trial by the French Thyroid Research Group. J Clin Endocrinol Metab 87: 4928-4934.

171. Zelmanovitz F, Genro S, Gross JL, 1998 Suppressive therapy with levothyroxine for solitary thyroid nodules: a double-blind controlled clinical study and cumulative meta-analyses. J Clin Endocrinol Metab 83: 3881-3885.

172. Gharib H, James EM, Charboneau JW, Naessens JM, Offord KP, Gorman CA, 1987 Suppressive therapy with levothyroxine for solitary thyroid nodules. A double-blind controlled clinical study. N Engl J Med 317: 70-75.

173. Mazzaferri EL, Young RL, 1981 Papillary thyroid carcinoma: a 10 year follow-up report of the impact of therapy in 576 patients. Am J Med 70: 511-518.

174. Auer J, Scheibner P, Mische T, Langsteger W, Eber O, Eber B, 2001 Subclinical hyperthyroidism as a risk factor for atrial fibrillation. Am Heart J 142: 838-842.

175. Cappola AR, Fried LP, Arnold AM, et al, 2006 Thyroid status, cardiovascular risk, and mortality in older adults. JAMA 295: 1033-1041.

176. Faber J, Galloe AM, 1994 Changes in bone mass during prolonged subclinical hyperthyroidism due to L-thyroxine treatment: a meta-analysis. Eur J Endocrinol 130: 350356.

177. Sawin CT, Geller A, Wolf PA, et al, 1994 Low serum thyrotropin concentrations as a risk factor for atrial fibrillation in older persons. N Engl J Med 331: 1249-1252.

178. Franklyn JA, Betteridge J, Daykin J, et al, 1992 Long-term thyroxine treatment and bone mineral density. Lancet 340: 9-13.

179. Cho YS, Lee HK, Ahn IM, et al, 2000 Sonographically guided ethanol sclerotherapy for benign thyroid cysts: results in 22 patients. AJR Am J Roentgenol 174: 213216.

180. Bennedbaek FN, Nielsen LK, Hegedus L, 1998 Effect of percutaneous ethanol injection therapy versus suppressive doses of L-thyroxine on benign solitary solid cold thyroid nodules: a randomized trial. J Clin Endocrinol Metab 83: 830-835.

181. Bennedbaek FN, Hegedus L, 1999 Percutaneous ethanol injection therapy in benign solitary solid cold thyroid nodules: a randomized trial comparing one injection with three injections. Thyroid 9: 225-233.
182. Dossing H, Bennedbaek FN, Karstrup S, Hegedus L, 2002 Benign solitary solid cold thyroid nodules: US-guided interstitial laser photocoagulation--initial experience. Radiology 225: 53-57.

183. Dossing H, Bennedbaek FN, Hegedus L, 2003 Ultrasound-guided interstitial laser photocoagulation of an autonomous thyroid nodule: the introduction of a novel alternative. Thyroid 13: 885-888.

184. Dossing H, Bennedbaek FN, Hegedus L, 2005 Effect of ultrasound-guided interstitial laser photocoagulation on benign solitary solid cold thyroid nodules - a randomised study. Eur J Endocrinol 152: 341-345.

185. Spiezia S, Vitale G, Di SC, et al, 2003 Ultrasound-guided laser thermal ablation in the treatment of autonomous hyperfunctioning thyroid nodules and compressive nontoxic nodular goiter. Thyroid 13: 941-947.

186. Pacella CM, Bizzarri G, Spiezia S, et al, 2004 Thyroid tissue: US-guided percutaneous laser thermal ablation. Radiology 232: 272-280.

187. Amabile G, Rotondi M, Chiara GD, et al, 2006 Lowenergy interstitial laser photocoagulation for treatment of nonfunctioning thyroid nodules: therapeutic outcome in relation to pretreatment and treatment parameters. Thyroid 16: 749-755.

188. Dossing H, Bennedbaek FN, Hegedus L, 2006 Effect of Ultrasound-Guided Interstitial Laser Photocoagulation on Benign Solitary Solid Cold Thyroid Nodules: One versus Three Treatments. Thyroid 16: 763-768.

189. Sherman SI, 2003 Thyroid carcinoma. Lancet 361: 501511.

190. Mazzaferri EL, Jhiang SM, 1994 Long-term impact of initial surgical and medical therapy on papillary and follicular thyroid cancer. Am J Med 97: 418-428.

191. DeGroot LJ, Kaplan EL, McCormick M, Straus FH, 1990 Natural history, treatment, and course of papillary thyroid carcinoma. J Clin Endocrinol Metab 71: 414-424.

192. Hay ID, Thompson GB, Grant CS, et al, 2002 Papillary thyroid carcinoma managed at the Mayo Clinic during six decades (1940-1999): temporal trends in initial therapy and long-term outcome in 2444 consecutively treated patients. World J Surg 26: 879-885.

193. Duntas L, Grab-Duntas BM, 2006 Risk and prognostic factors for differentiated thyroid cancer. Hell J Nucl Med 9: 156-162.

194. Soh EY, Clark OH, 1996 Surgical considerations and approach to thyroid cancer. Endocrinol Metab Clin North Am 25: 115-139.

195. Sanders LE, Cady B, 1998 Differentiated thyroid cancer: reexamination of risk groups and outcome of treatment. Arch Surg 133: 419-425.

196. Grebe SK, Hay ID, 1996 Thyroid cancer nodal metastases: biologic significance and therapeutic considerations. Surg Oncol Clin N Am 5: 43-63.

197. Scheumann GF, Gimm O, Wegener G, Hundeshagen H, Dralle H, 1994 Prognostic significance and surgical management of locoregional lymph node metastases in papillary thyroid cancer. World J Surg 18: 559-567.

198. Tisell LE, Nilsson B, Molne J, et al, 1996 Improved 
survival of patients with papillary thyroid cancer after surgical microdissection. World J Surg 20: 854-859.

199. Kouvaraki MA, Shapiro SE, Fornage BD, et al, 2003 Role of preoperative ultrasonography in the surgical management of patients with thyroid cancer. Surgery 134: 946-954.

200. Pacini F, Schlumberger M, Harmer C, et al, 2005 Postsurgical use of radioiodine $\left({ }^{123} \mathrm{I}\right)$ in patients with papillary and follicular thyroid cancer and the issue of remnant ablation: a consensus report. Eur J Endocrinol 153: 651659.

201. Wong JB, Kaplan MM, Meyer KB, Pauker SG, 1990 Ablative radioactive iodine therapy for apparently localized thyroid carcinoma. A decision analytic perspective. Endocrinol Metab Clin North Am 19: 741-760.

202. Sawka AM, Thephamongkhol K, Brouwers M, Thabane L, Browman G, Gerstein HC, 2004 Clinical review 170: A systematic review and metaanalysis of the effectiveness of radioactive iodine remnant ablation for well-differentiated thyroid cancer. J Clin Endocrinol Metab 89: 3668-3676.

203. Samaan NA, Schultz PN, Hickey RC, et al, 1992 The results of various modalities of treatment of well differentiated thyroid carcinomas: a retrospective review of 1599 patients. J Clin Endocrinol Metab 75: 714-720.

204. Lin JD, Chao TC, Huang MJ, Weng HF, Tzen KY, 1998 Use of radioactive iodine for thyroid remnant ablation in well-differentiated thyroid carcinoma to replace thyroid reoperation. Am J Clin Oncol 21: 77-81.

205. Lewis BD, Hay ID, Charboneau JW, McIver B, Reading CC, Goellner JR, 2002 Percutaneous ethanol injection for treatment of cervical lymph node metastases in patients with papillary thyroid carcinoma. AJR Am J Roentgenol 178: 699-704.

206. Cooper DS, Specker B, Ho M, et al, 1998 Thyrotropin suppression and disease progression in patients with differentiated thyroid cancer: results from the National Thyroid Cancer Treatment Cooperative Registry. Thyroid 8: 737-744.

207. Pujol P, Daures JP, Nsakala N, Baldet L, Bringer J, Jaffiol C, 1996 Degree of thyrotropin suppression as a prognostic determinant in differentiated thyroid cancer. J Clin Endocrinol Metab 81: 4318-4323.

208. Scollo C, Baudin E, Travagli JP, et al, 2003 Rationale for central and bilateral lymph node dissection in sporadic and hereditary medullary thyroid cancer. J Clin Endocrinol Metab 88: 2070-2075.

209. Brierley J, Tsang R, Simpson WJ, Gospodarowicz M, Sutcliffe S, Panzarella T, 1996 Medullary thyroid cancer: analyses of survival and prognostic factors and the role of radiation therapy in local control. Thyroid 6: 305-310.

210. Saad MF, Guido JJ, Samaan NA, 1983 Radioactive iodine in the treatment of medullary carcinoma of the thyroid. J Clin Endocrinol Metab 57: 124-128.

211. Shimaoka K, Schoenfeld DA, DeWys WD, Creech RH, DeConti R, 1985 A randomized trial of doxorubicin versus doxorubicin plus cisplatin in patients with advanced thyroid carcinoma. Cancer 56: 2155-2160.
212. Haigh PI, Ituarte PH, Wu HS, et al, 2001 Completely resected anaplastic thyroid carcinoma combined with adjuvant chemotherapy and irradiation is associated with prolonged survival. Cancer 91: 2335-2342.

213. Holm LE, Blomgren H, Lowhagen T, 1985 Cancer risks in patients with chronic lymphocytic thyroiditis. N Engl J Med 312: 601-604.

214. Pyke CM, Grant CS, Habermann TM, et al, 1992 NonHodgkin's lymphoma of the thyroid: is more than biopsy necessary? World J Surg 16: 604-609.

215. Tsang RW, Gospodarowicz MK, Sutcliffe SB, Sturgeon JF, Panzarella T, Patterson BJ, 1993 Non-Hodgkin's lymphoma of the thyroid gland: prognostic factors and treatment outcome. The Princess Margaret Hospital Lymphoma Group. Int J Radiat Oncol Biol Phys \%20; 27: 599-604.

216. Renshaw AA, 2002 Hürthle cell carcinoma is a better gold standard than Hurthle cell neoplasm for fine-needle aspiration of the thyroid: defining more consistent and specific cytologic criteria. Cancer 96: 261-266.

217. Erdem E, Gulcelik MA, Kuru B, Alagol H, 2003 Comparison of completion thyroidectomy and primary surgery for differentiated thyroid carcinoma. Eur J Surg Oncol 29: 747-749.

218. Shaha AR, Jaffe BM, 1992 Completion thyroidectomy: a critical appraisal. Surgery 112: 1148-1152.

219. Stojadinovic A, Ghossein RA, Hoos A, et al, 2001 Hurthle cell carcinoma: a critical histopathologic appraisal. J Clin Oncol 19: 2616-2625.

220. Miller JM, Kini SR, Hamburger JI, 1985 The diagnosis of malignant follicular neoplasms of the thyroid by needle biopsy. Cancer 55: 2812-2817.

221. Schlinkert RT, van Heerden JA, Goellner JR, et al, 1997 Factors that predict malignant thyroid lesions when fineneedle aspiration is "suspicious for follicular neoplasm". Mayo Clin Proc 72: 913-916.

222. Hamburger JI, 1994 Diagnosis of thyroid nodules by fine needle biopsy: use and abuse. J Clin Endocrinol Metab 79: 335-339.

223. Miettinen M, Karkkainen P, 1996 Differential reactivity of HBME-1 and CD15 antibodies in benign and malignant thyroid tumours. Preferential reactivity with malignant tumours. Virchows Arch 429: 213-219.

224. Xu XC, el-Naggar AK, Lotan R, 1995 Differential expression of galectin-1 and galectin-3 in thyroid tumors. Potential diagnostic implications. Am J Pathol 147: 815822 .

225. Ravinsky E, Safneck JR, 1988 Differentiation of Hashimoto's thyroiditis from thyroid neoplasms in fine needle aspirates. Acta Cytol 32: 854-861.

226. Braga M, Cavalcanti TC, Collaco LM, Graf H, 2001 Efficacy of ultrasound-guided fine-needle aspiration biopsy in the diagnosis of complex thyroid nodules. J Clin Endocrinol Metab 86: 4089-4091.

227. Yeh MW, Demircan O, Ituarte P, Clark OH, 2004 Falsenegative fine-needle aspiration cytology results delay treatment and adversely affect outcome in patients with thyroid carcinoma. Thyroid 14: 207-215. 